\title{
Religiosity and Transcendental Future Time Perspective as Predictors of Risk Taking Tendency
}

\author{
Masnaeni Ahmad ${ }^{1}$, Rahmat Hidayat ${ }^{2}$ \\ \{naeniahmad@gmail.com ${ }^{1}$, r.hidayat@ugm.ac.id ${ }^{2}$ \} \\ Department of Nursing, Poltekkes Kemenkes Mamuju, Jl Poros Mamuju Kalukku KM 16 Kalukku, \\ Mamuju 91561, Indonesia, ${ }^{1}$ \\ Department of Psychology, Universitas Gadjah Mada J1 Sosio Humaniora Bulaksumur, Yogyakarta \\ 55281, Indonesia ${ }^{2}$
}

\begin{abstract}
This study aimed to examine the relationship between risk-taking tendency and two other variables assumed to be antecedents, i.e., religiosity, and transcendental future time perspective. This study used a quantitative approach by survey method in collecting data. Respondents of this study $(\mathrm{N}=203)$ are civil servants from thirteen government institutions. Three questionnaires were used in collecting data which were risk-taking scale, religiosity scale, and transcendental future time perspective inventory. The result of this study showed that people with high religiosity is low in terms of economics, ethics, social, health, and recreational risk taking tendency. Strong belief about the afterlife would support people avoiding economics, ethics, health, social, and recreational risk taking tendency. In choosing a domain of risk taking, most of the respondents were influenced by the environment, especially their workplace culture and their status as a civil servant.
\end{abstract}

Keywords: risk taking tendency; religiosity; transcendental future time perspective.

\section{Introduction}

The Civil Servants are Indonesian citizens who fulfill certain conditions, appointed as Civil Servants of the State by officials who are authorized and entrusted with duties in a state position or entrusted with other state duties, and paid based on the prevailing laws and regulations [1]. Same as other professions, civil servants also have the possibility of experiencing stress. Northwestern National Life and Families and Work Institute consecutively reported that $40 \%$ of workers feel that their work is very stressful, and $26 \%$ of workers suffer from stress due to their work. The result of research by Yale University reported that $29 \%$ of workers felt sufficient or stressed at work [2]. A study by Parslow et al. of 806 Australian government employees showed that stress on female government employees increased along with long working hours and their inability to control work, while in male government employees, stress levels increased along with a sense of insecurity in doing work and also weak in controlling work [3]. The study in Taiwan also produced a positive correlation between work stress and its causal factors derived from job demands, lack of decision-making authority, and lack of social support [4].

According to the WHO (2016), there are about 35 million people affected by depression, 60 million people affected by bipolar, 21 million affected by schizophrenia, and 47,5 million affected by dementia. Data of Riskesdas 2013 showed a prevalence of emotional, mental 
disorder indicated by symptoms of depression and anxiety for age 15 years old and upward, reached around 14 million people or $6 \%$ of the country`s population. While the prevalence of the severe mental disorder, like schizophrenia, reached 400,000 people or as many as 1.7 per 1,000 populations [5].

Several studies had shown that the adverse effects of stress on employees including increased work absenteeism, low satisfaction and work productivity, increased number of workplace accidents, hypertension, coronary heart disease, physical and mental disorders, costs of illness and accidents related to stress, early retirement, and even suicidal [6], [7]. Job stress on employees affects performances, especially the ability to concentrate. Job stress becomes part of occupational health and safety risks when work demands are greater than the capacity, resources, and capabilities of workers that occur in a long time [8].

Risk is a probabilistic situation and has an adverse impact. Probabilistic here means that the risk leads to negative events that may occur, its severity, intensity, and duration. In terms of the impact, risk leads to consequences after events, such as property losses, suicidal, and so on [9]. Some factors that influence risk taking include age [10], gender [11], [12], uncertainty [13], [14], feelings [15], health [16], and religiosity.

Malwonski stated that religiosity is related to the desire to control and reconcile with pure risk which can significantly cause losses and cannot be fully controlled by sophisticated technologies such as natural disasters, illness, and death [17]. This is in line with non-rational strategies in the form of trust, hope, and religion that enable individuals to face critical or seemingly impossible situations [14]. Religiosity also positively correlates with values that emphasize transcendent aspects, maintain tradition, and protect oneself from uncertainty.

Threats arising from risk taking can be extreme, in the form of death. Death is a threat that is believed to be certain to occur [18]. Fear of death can be a motivation to be more religious. Religious people believe in the coming of God's help in every difficulty faced by humans, including the threat of taking risks taken. Although it is threatening, humans believe that death is the beginning of an eternal afterlife. This belief by Zimbardo and Boyd is called the Transcendental Future Time Perspective (TFTP). TFTP did not examine what happened after death, but how the belief in the existence of the afterlife affects human life in the present, including one of the human tendencies to take risks. This belief is what raises hope in every possibility that is the result of human calculation regarding uncertainty. This belief is what strengthens individuals to face uncertainty by taking risks [19]. Based on the description above, this study hypothesizes that there is a relationship between the tendency to take risks with religiosity and transcendental future time perspective.

\section{Method}

This study is survey model of cross sectional, with a research population of all Civil Servants of Selayar Islands Regency. The research sample was determined by incidental sampling, that are the civil servants who were met during the study period, aged between 25 50 years, had worked for at least one year and were willing to become research respondents by filling out questionnaires prepared by researchers. This is done with the consideration that data collection is carried out during employee working hours. Data collection located in thirteen Selayar Islands Regency government offices. The dependent variables are the factors that are affected by the independent variable, which in this study is the tendency to take risks. While 
the independent variable is a variable that is thought to influence the dependent variables, which in this study is religiosity and transcendental future time perspective.

The instruments were used a modification of risk-taking scales developed by Blais and Weber covering ethics, finance, health/safety, social and recreational domains [20] and consisted of 22 items. Respondents were asked to circle the numbers in the choice of answers according to reality or by their daily habits, not what they think. This instrument used a Likert Scale with 5 categories, which are "strongly disagree," "disagree," "neutral," "agree," and "strongly agree". Score 1 for "strongly disagree", 2 for "disagree", 3 for "neutral", 4 for "agree" and 5 for "strongly agree". Religiosity questionnaire was a modification of the concept of religiosity dimensions proposed by Glock and Stark, which are beliefs, religious rituals and knowledge and observations consisting of 20 items. Respondents were asked to circle the numbers in the choice of answers according to reality or by their daily habits, not what they think. This instrument uses a Likert Scale with 5 categories, which are "strongly disagree," "disagree", "neutral", "agree" and "strongly agree". Score 1 for "strongly disagree", 2 for "disagree", 3 for "neutral", 4 for "agree" and 5 for "strongly agree". The transcendental future time perspective (TFTP) questionnaire consists of nine statements modified from the Transcendental Future Time Perspective Inventory [19] in the form of three aspects, which are beliefs about the concept of creation, belief in the afterlife and belief in God's power. Respondents were asked to circle the numbers in the choice of answers according to reality or in accordance with their daily habits, not what they think. This instrument uses a Likert Scale with 7 categories, namely "Strongly Disagree", "Disagree", "Slightly Disagree", "Neutral", "Slightly Agree", "Agree" and "Strongly Agree". Score 1 for "Strongly Disagree", 2 for "Disagree", 3 for "Slightly Disagree", 4 for "Neutral", 5 for "Slightly Agree", 6 for "Agree" and 7 for "Strongly Agree".

Data were analyzed descriptively to present a demographic picture of the respondents of this study including age, gender, level of education, years of service and religion. Univariate analysis is used to see the frequency characteristics of variables while bivariate analysis is used to determine the relationship between the independent variable and dependent variables. Linear regression is used to determine the linear relationship between a dependent variable and one or more independent variables. The statistical analysis uses SPSS for Windows.

\section{Results}

This study describes the foot arch type data which is associated with age (year), weight (kilogram), height (centimeter) and body mass index $\left(\mathrm{kg} / \mathrm{m}^{2}\right)$ to show the profile of the research subjects (Table 1). It appears that in the low-arched foot type has the highest tendency of body weight, height and body mass index, compared with the other two foot arch types.

A total of 203 respondents filled out the research questionnaire with the age range of respondents being 25 to 56 years. Table 1 on below show respondents were male as many as 103 respondents $(50.7 \%)$ and female as many as 100 people $(49.3 \%)$. The education level category consists of bachelor's degree $(\mathrm{n}=103 ; 50.7 \%)$, diploma graduate $(\mathrm{n}=39 ; 19.2 \%)$, senior high school $(\mathrm{n}=58 ; 28.6 \%)$ and junior high school $(\mathrm{n}=3 ; 1.5 \%)$. For the service period category is classified into the work experience of $1-5$ years $(n=63 ; 31 \%), 6-10$ years $(n=37$, $8.2 \%), 11-20$ years $(\mathrm{n}=53,26.1 \%)$ and more than 21 years $(\mathrm{n}=50 ; 24.6 \%)$. There are only two religious categories which are Islam $(\mathrm{n}=200 ; 98.5 \%)$ and Christianity $(\mathrm{n}=3 ; 1.5 \%)$. 
Table 1. Demographic Characteristics of Research Respondents

\begin{tabular}{lcc}
\hline Characteristics & Frequency & Percentage \\
\hline Age & 56 & 27.6 \\
25-30 Years Old & 81 & 39.9 \\
31-40 Years Old & 44 & 21.7 \\
41-50 Years Old & 22 & 10.8 \\
More Than 50 Years Old & & \\
Gender & 103 & 50,7 \\
Male & 100 & 49,3 \\
Female & & \\
Education Level & 103 & 50,7 \\
Bachelor's Degree & 39 & 19,2 \\
Diploma Graduate & 58 & 28,6 \\
Senior High School & 3 & 1,5 \\
Junior High School & & \\
Work Experience & 63 & 31 \\
1-5 Years & 37 & 18,2 \\
6-10 Years & 53 & 26,1 \\
11-20 Years & 50 & 24,6 \\
More Than 20 Years & & \\
Religion & 200 & 98,5 \\
Islam & 3 & 1,5 \\
Christianity & & \\
\hline
\end{tabular}

Table 2 Results of Linear Regression Analysis

\begin{tabular}{llll}
\hline Variables & P-value & r & Direction \\
\hline Religiosity, TFTP & 0.000 & 0.154 & negative \\
\hline
\end{tabular}

Table 2 showed that religiosity and transcendental future time perspective significantly has a relationship with the tendency to take risks with a correlation value (r) of 0.15 and a negative correlation direction. This means there is a relationship between the risk taking tendency with religiosity and transcendental future time perspective.

Table 3. Results of Bivariate Correlation Analysis

\begin{tabular}{llll}
\hline Variables & P-value & r & Direction \\
\hline Religiosity & 0.000 & 0.34 & negative \\
Transcendental future time perspective & 0.003 & 0.21 & negative \\
\hline
\end{tabular}

Table 3 showed that religiosity significantly has a relationship with the tendency to take risks with a correlation value (r) of 0.34 and a negative correlation direction. This means that the more religious a person is, the tendency to take risks will be low. Transcendental future time perspective with a tendency to take risks also shows a significant correlation with a p-value of 0.003 . The correlation value (r) is 0.21 , and the direction of correlation is negative. It means the higher the level of one's confidence in the afterlife, the lower the risk of taking the risk. 
Table 4. Results of Bivariate Correlation Analysis of the Risk Taking Tendency to the Dimensions of Religiosity

\begin{tabular}{llll}
\hline Variables & $\mathrm{p}$-value & $\mathrm{R}$ & Direction \\
\hline Belief & 0,000 & 0,28 & Negative \\
Worship ritual & 0,000 & 0,37 & Negative \\
Knowledge and Observation & 0,003 & 0,20 & Negative \\
\hline
\end{tabular}

Table 4 showed that each dimension of religiosity correlates with the tendency to take risks. Based on the strength of the relationship, the ritual dimension of worship has the strongest bond compared to the other two dimensions because it has a value of (r) of 0.37 . This means that the more often a person performs religious worship, the lower the tendency to take risks.

Table 5. Results of Correlation Analysis Risk Taking Tendency to TFTP Aspects

\begin{tabular}{llll}
\hline Variables & p-value & $\mathrm{r}$ & Direction \\
\hline Belief about the concept of creation & 0,001 & 0,22 & negative \\
Belief in the afterlife & 0,02 & 0,15 & negative \\
Belief in the power of God & 0,40 & 0,01 & negative \\
\hline
\end{tabular}

Table 5 showed that the TFTP aspect has a correlation with the tendency to take risks. Based on the strength of the relationship, the belief aspect of the concept of creation has the strongest bond compared to the aspect of belief in the existence of the afterlife because it had a value (r) of 0.22 . This means that the higher a person's confidence in the existence of God as creator, soul and spirit, miracles and God's laws governing human life, the lower the tendency to take risks.

\section{Discussion}

Based on the results, it is known that future time perspective religiosity and transcendental have a negative relationship with risk taking tendencies. Religiosity has a negative relationship with the tendency to take risks in terms of economic, ethical, health, social, and recreational. While the transcendental future time perspective showed a negative relationship with the tendency to take risks in terms of economic, ethical, health, social, and recreational.

Someone who believes in the existence of God also believes that in every decision making in his life will have an impact on his life. Religious individuals believe that the good or bad of their luck is in God's power. This affects their decision making, including risk taking. Religious people avoid the risk that there will be no remorse for the consequences of risk taking [21]. The findings in this study are that religious people avoid remorse by avoiding taking risks in terms of economic, ethical, health, social, and recreational.

Religion is a non-rational risk management strategy, a society that avoids the risk is more do worship ritual than people who intend to take risks. Religious beliefs can be used as an awareness to avoid the risk of obtaining benefits in the afterlife. Belief in the afterlife makes one avoid risk taking [22].

Beliefs about all actions taken while living in the world will get a reward in the after-life in line with the beliefs of the Selayar people about "all ri boko". "Allo ri Boko" is lexically 
meaning a day later or hereafter life. It can also be interpreted as a future which implies a day that no one can see, but surely there is. There are values that develop in the Selayar society regarding the concept of obtaining happiness in the world and the after-life. The base of happiness in the world and the after-life is sincere negating the self-destructive ones and seeking virtue for God's servants [23].

This belief then underlies the low risk taking in terms of risk taking in terms of economic, ethical, health, social, and recreational. Economic domain is related to the consequences of the ongoing financial life of someone who can also affect his family. In other words, if he takes economic risks, the consequences of that decision are not only borne by himself but also by the family he is responsible for. This is in line with the results of research which states that debt behavior is influenced by family roles. Debt behavior will ask for opinions from spouses, families, and even consider their social environment [24].

There is a fundamental difference between pure risk and speculative risk. Pure risk is a risk that leads to a situation that does not require effort as a prefix position (such as a car accident and accident). While speculative risk is a combination of opportunities for profit and loss, such as gambling. The risks of recreational and health include pure risk. Individuals do not make any effort to face the risk of being in control of themselves. For example, someone decides to recreation to a new and foreign place. He has no control to deal with the appearance of bad weather during the trip, likewise with health risks. Individuals cannot avoid themselves suffering from a deadly disease even though he has avoided the wrong diet or an unhealthy lifestyle. The risk of stress and mental disorders differs according to age, gender, education, and occupation as well as the chronic diseases experienced [25].

Meanwhile, economic, ethical, financial, and social risks fall into the category of speculative risk. The consequences of this risk are profit or loss. One factor that causes low speculative risk taking is the existence of a sense of security in economic terms. The certainty of monthly salary and promotion of routine become an overview of results orientation for civil servants. A life that has a steady income every month directs them to a situation of certainty. Risk taking is based on certainty orientation and uncertainty of the results to be obtained and achievement motivation. In an uncertain results orientation, individuals with high achievement motivation will choose moderate risk, and individuals who are oriented towards certainty will take a low risk [26].

The life of the Civil Servants emphasizes more on structural relationships that are full of bureaucracy. Civil servants with positions and ranks will create rigid communication so that the perspectives on normative behavior are based on organizational agreements held by organizational officials. Risk taking by subordinates is influenced by superiors' risk taking. Superiors who show a culture of risk taking will direct their subordinates to take risks to improve innovative performance [27]. The low risk taking in civil servants because of the bureaucratic work culture shows the responsibility of a job as a superior area. So that superiors are more likely to take risks both in terms of ethics and social, this is in line with the concept of trust in leaders. Trust in leaders plays an important role in risk taking. The greater the trust in the leader, the lower risk taking will be carried out.

The findings in this study are slightly different from the research [28], which stated that there is no correlation between religiosity and risk taking. Differences in research findings are caused by variations in research subjects involved in this study. The subject of Miller's research, which is intended as an eastern society, is represented by Japanese and Indian people with the dominance of the religions adopted are Hinduism and Buddhism. While the subjects in this study were civil servants in the Selayar Islands, where the dominance of the religion adopted was Islam. Also, in Miller's study, only ritualistic aspects that can show a relationship 
between religiosity and the tendency to take risks in Indian society. Meanwhile, religiosity dimensions proposed by Glock and Stark [30] which are beliefs, religious rituals, and knowledge and observations showed a significant correlation with risk taking.

\section{Conclusion}

Based on this research, we found that a person with high religiosity is low in terms of economics, ethics, social, health, and recreational risk-taking tendency. Strong belief about the afterlife would support people avoiding economics, ethics, health, social, and recreational risks. Civil servant's risk-taking tendency is influenced by workplace culture.

Acknowledgments. We would like to say thank you to all respondents, Selayar Islands Regent, Faculty of Psychology Universitas Gadjah Mada and Poltekkes Kemenkes Mamuju.

\section{References}

[1] Pemerintah Republik Indonesia.: Undang-Undang Negara Republik Nomor 5 Tahun 2014 tentang Aparatur Sipil Negara. Sekretariat Negara. Jakarta. (2014)

[2] NIOSH.: Stress At Work. URL http://www.cdc.gov/niosh/docs/99-101/default.html (accessed 1.05.17). (1999)

[3] Parslow, R. A., Jorm, A. F., Christensen, H., Broom, D. H., Strazdins, L., \& D' Souza, R. M.: The impact of employee level and work stress on mental health and GP service use: an analysis of a sample of Australian government employees. BMC public health. Vol. 4, pp. 78-90 (2004)

[4] Tsai, Y.C. dan, Liu, C.H.: Factors And Symptoms Associated With Work Stress And Health Promoting Lifestyles Among Hospital Staff: A Pilot Study In Taiwan. BMC Health Serv. Res. Vol. 12, pp. 1-8. (2012)

[5] Kementerian Kesehatan Republik Indonesia.: Peran Keluarga Dukung Kesehatan Jiwa Masyarakat. (2016)

[6] Malgorzata, Chojnacka, Krzysztof Witkowski. Determinants of stress in the company perfecting quality. Management. Vol. 16.pp. 36-50 (2012)

[7] Schneiderman N, Gail Ironson, and Scott D. Siegel. Stress and health: psychological, behavioral, and biological determinants. Annual review of clinical psychology; Vol.1.pp 607-28 (2005)

[8] International Labour Organization. 2014. Safety and Health at Work: A Vision for Sustainable Prevention. Germani: ILO.(2016)

[9] Breakwell, GM.: The Psychology of Risk. New York. Cambridge University Press. (2007)

[10] Duell, Natasha \& Steinberg, Laurence \& Icenogle, Grace \& Chein, Jason \& Chaudhary, Nandita \& Giunta, Laura \& A. Dodge, Kenneth \& Fanti, Kostas \& E. Lansford, Jennifer \& Oburu, Paul \&. Journal of Youth and Adolescence. Vol. pp. 47. (2017)

[11] Freese, J.: Risk Preferences and Gender Differences in Religiousness: Evidence from the World Value Survey. Review of Religious Research. Vol. 46, pp. 88-91. (2004)

[12] Pawlowski, B, Atwal, R, Dunbar, RIM.: Sex Differences in Everyday Risk-Taking Behavior in Humans. Evolutionary Psychology. Vol. 6, pp. 29-42. (2008)

[13] Aven, T.: On how to approach risk and uncertainty to support decision-making. Palgrave Macmillan Journals. Vol. 6, pp. 27-39. (2004)

[14] Zinn, JO.: Everyday Strategies for Managing Risk and Uncertainty. Health, Risk \& Society. Vol. 10, pp. 439-450. (2008)

[15] Chou, K, Lee, TMC, Ho, AHY.: Does mood state change risk taking tendency in older adults.

Psychology and Aging. Vol. 22, pp. 310-318. (2007) 
[16] O'Brien, EM, Mindell, JA.: Sleep and Risk-Taking Behavior in Adolescent. Behavioral Sleep Medicine. Vol. 3, pp. 113-133. (2005)

[17] Shu, T, Sulaeman, J, Yeung, PE.: Local Religious Beliefs and Organizational Risk-Taking Behaviors. JEL. (2010)

[18] Hidayat, K.: Psikologi Kematian Mengubah Ketakutan Menjadi Optimisme. Jakarta: Penerbit Hikmah

[19] Zimbardo, P, Boyd, J.: The Time Paradox. Using the new psychology of time to your advantage. London: Rider Books. (2008)

[20] Blais, A, Weber, EU.: A Domain-specific Risk-attitude Scale: Measuring Risk Perceptions and Risk Behavior. Journal of Behavioral Decision Making. Vol. 15, pp. 263-290. (2002)

[21] Tuhin, K, D.: A regret analysis of religiosity. Journal for Interdisciplinary Research on Religion and Science. Vol. 4, pp. 215-219. (2009)

[22] Osoba, B, J.: Risk, discounting, and religious choice. Evidence from panel data1. University of Texas at El Paso Working Paper. (2004)

[23] Wahid, S.: Manusia Makassar. Makassar: Penerbit Pustaka Refleksi. (2007)

[24] Widakdo, G, Besral.:Efek penyakit kronis terhadap gangguan mental emosional. Kesmas: Jurnal Kesehatan Masyarakat Nasional. Vol. 7, pp. 309-16. (2013)

[25] Sorrentino, R. M. \& Hewitt, E. C.: Risk Taking in Games Chance and Skill Information and Effctive Influence on Choice Behavior. Journal of Personality and Social Psyhchology. Vol. 62, pp. 522-533. (1992)

[26] Llopis, O, García-Granero, A, Fernández-Mesa, A, Alegre-Vidal, J.: Managers' risk taking behavior and innovation performance: the mediating influence of employees' perceived risk raking climate. Proceedings of the 2013 EU-SPRI Forum Conference, Madrid, Italy, April. (2013)

[27] Miller, A. S.: Going to Hell in Asia. The Relationship between Risk and Religion in A Cross Cultural Setting. Review of Religious Research. Vol. 42, pp. 5-18. (2000)

[28] Ancok, D, Suroso, F. S.: Psikologi Islami, Solusi atas Problem-problem Psikologi. Yogyakarta: Pustaka Pelajar. (2008.) 